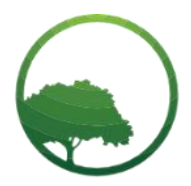

Research in Business \& Social Science

IJRBS VOL 10 NO 3 ISSN: 2147-4478

\title{
The impact of external funding flow on Jordan's GDP (1997-2017)
}

\author{
(D) Ahmad Mashal (a)* (D) Emad Ahmad (b) (D) Lama Nasrawi (c) (D) Anas Ghazalat ${ }^{(d)}$ \\ (a) Ph.D., Associate Professor, Arab Open University, Jordan \\ (b) Ph.D., Assistant Professor, Dean, Arab Open University, Jordan \\ ${ }^{(c)}$ Independent Researcher \\ ${ }^{(d)}$ Ph.D., Assistant Professor, Arab Open University, Jordan
}

\author{
A R T I CLE INFO \\ Article history: \\ Received 12 April 2021 \\ Received in rev. form 26 April 2021 \\ Accepted 28 April 2021 \\ Keywords: \\ External Funding, Grants, Soft loans, \\ Foreign Direct Investment, The \\ Jordanian Migrant's Worker's \\ Remittances, Migrant's Worker's \\ Remittances, GDP \\ JEL Classification: \\ G31, G23
}

\begin{abstract}
A B S T R A C T
The main objective of this study is to investigate the impact of external funding flow on Jordan's GDP (1997 - 2017) focusing on variables such as; grants (GR), soft loans (LN), foreign direct investment (FDI), and the Jordanian migrant worker's remittances (JMWR) on Jordan's GDP which represent the dependent variable through using the E-Views statistical program and multiple regressions analysis. Previous studies showed the significant and non-significant impacts of the flow of external funding on the economy. In this study the researchers analyzed the impact of external funding flow on Jordan's GDP for the period (1997-2017) and found that grants (GR) and foreign direct investment (FDI) have a statistically significant impact on Jordan's GDP; in contrast, soft loans (LN) and the Jordanian migrant's worker's remittances (JMWR) have no statistically significant impact on Jordan's GDP for the same period. This study filled the gap and expanded the analysis to test whether there is an impact of grants independently of the soft loans on Jordan's GDP and vice versa, in addition, the study investigated the impact of other variables such as; foreign direct investment (FDI), and the Jordanian migrant worker's remittances (JMWR).
\end{abstract}

(C) 2021 by the authors. Licensee SSBFNET, Istanbul, Turkey. This article is an open access article distributed under the terms and conditions of the Creative Commons Attribution (CC BY) license (http://creativecommons.org/licenses/by/4.0/).

\section{Introduction}

A group of economist believes that an economy is a machine that produces economic output through inputs (labor, land, equipment) that helps to increase the production and leads to economic growth; so the outputs can be improved by adding more inputs or creating new things that contribute to increasing the production (Mladen, 2015). In developing countries, funding is an essential element in achieving economic and political objectives, and it is also necessary to overcome the economic, political, and social challenges in developing countries. Economically, funding means funds that are provided by an organization or a government for a certain purpose (Mladen, 2015).

The World Bank in 2018, classified Jordan as the smallest economies in the MENA region. Jordan's population was $(9,702,353)$ in 2017 with a GDP of $\$ 40,068$ billion in the same year, which considered Jordan as a country with a middle- income country. Jordan has relied heavily on foreign aid and other inflows to support the government's budget deficit. According to the reports and numbers received from the Ministry of Planning and International Cooperation (MOPIC) in 2019, Jordan has received approximately \$ 4.91 billion as a foreign aid from the United States of America alone from 1997 until 2017. As a result of political and economic developments in Jordan; foreign aid has increased in the form of grants, soft loans and military aid from the United States of America. In 2003, Jordan has received crude oil supported by Saudi Arabia and the United Arab Emirates (MOPIC, 2019). In the mid of 1990, foreign aid has increased in Jordan to help the local economy and maintain internal stability, so it has received foreign aid (grants, soft loans, and technical assistance) from donor countries.

* Corresponding author. ORCID ID: 0000-0003-4368-3908

(C) 2021 by the authors. Hosting by SSBFNET. Peer review under responsibility of Center for Strategic Studies in Business and Finance. https://doi.org/10.20525/ijrbs.v10i3.1133 
This study aims to examine the impact of external funding flow on Jordan's GDP (1997 - 2017) focusing on variables such as; grants (GR), soft loans (LN), foreign direct investment (FDI), and the Jordanian migrant worker's remittances (JMWR) on Jordan's GDP which represent the dependent variable through using the $\mathrm{E}$-Views statistical program and multiple regressions analysis.

Previous studies showed significant and non-significant impact of the flow of external funding on the economy. In our study, we examined the impact of external funding flow on Jordan's GDP for the period (1997-2017) and found that grants (GR) and foreign direct investment (FDI) have a statistically significant impact on Jordan's GDP; in contrast, soft loans (LN) and the Jordanian migrant's worker's remittances (JMWR) have no statistically significant impact on Jordan's GDP for the same period.

This study filled the gap and expanded the analysis to test whether there is an impact of grants independently of the soft loans on Jordan's GDP and vice versa, in addition, the study investigated the impact of other variables such as; foreign direct investment (FDI), and the Jordanian migrant worker's remittances (JMWR).

\section{Literature Review}

\section{Conceptual Background}

Jordan is one of the countries that realized the importance of foreign direct investment early, so recently it took the foreign direct investment (FDI) as an instrument of economic openness by providing an appropriate investment climate to attract foreign direct investments, regardless of the difficult circumstances in the region (CBJ, 2017). From 2007 to 2008, the global financial crisis has affected the foreign direct investment in Jordan, so in 2006, the proportion of foreign direct investment was (23.5\%) of GDP began to decline in 2007 to (15.3\%) mainly due to conflicts occurred in neighboring countries which led the investors to change their tendency to invest in Jordan due to instability in the MENA region (JIC, 2017).

A statistic published by the Central Bank of Jordan in 2017, indicated that there has been a significant decrease in the volume of foreign direct investment from $\$ 2$ billion to $\$ 1,548.2$ million (2008- 2012), which indicated that there is a problem in attracting foreign direct investment to Jordan because of the existence of a global financial crisis and the impact of Arab Spring crisis on the Arab countries at that time period. Despite the political and economic circumstances that faced Jordan from years 2014 to 2016 , especially in the Arab Spring period (the Syrian war, the war of Yemen) and the closure for the borders of the neighboring countries with Jordan; in addition to the existence of regulations that set by the Jordan investment commission (JIC), Jordan managed to maintain the ratio of foreign direct investment which was amounted in 2017 to (5\%) of the GDP in Jordan (CBJ, 2017).

Table (1) showed the size of foreign aid granted to Jordan from (1997- 2017) (MOPIC, 2019).

Table 1: Total of foreign aid to Jordan (1997 -2017) (\$ US Million Dollars)**

\begin{tabular}{ll}
\hline Year & Total of foreign aid \\
\hline $\mathbf{1 9 9 7}$ & 557 \\
\hline $\mathbf{1 9 9 8}$ & 621.5 \\
\hline $\mathbf{1 9 9 9}$ & 706 \\
\hline $\mathbf{2 0 0 0}$ & 675 \\
\hline $\mathbf{2 0 0 1}$ & 641 \\
\hline $\mathbf{2 0 0 3}$ & 596.6 \\
\hline $\mathbf{2 0 0 4}$ & 1490.1 \\
\hline $\mathbf{2 0 0 5}$ & 615.52 \\
\hline $\mathbf{2 0 0 6}$ & 641.207 \\
\hline $\mathbf{2 0 0 7}$ & 675 \\
\hline $\mathbf{2 0 0 8}$ & 680.35 \\
\hline $\mathbf{2 0 1 0}$ & 1137.5 \\
\hline $\mathbf{2 0 1 1}$ & 1374.7 \\
\hline $\mathbf{2 0 1 2}$ & 1133.5 \\
\hline $\mathbf{2 0 1 3}$ & 733.31 \\
\hline $\mathbf{2 0 1 4}$ & 3051.4 \\
\hline $\mathbf{2 0 1 5}$ & 2632.163 \\
\hline $\mathbf{2 0 1 7}$ & 1919.867 \\
\hline Total & 2667.827 \\
\hline
\end{tabular}

** Without additional grants to the Syrian crisis; Source: MOPIC, 2019

The Jordanian migrant worker's remittances have grown to become an important financial source which has become an important element to improve the economy in Jordan. In which these remittances are spent on the consumption of essential items (such as food, clothing, medicines ... etc.) and that are consumed by households that affect positively the macroeconomic in Jordan. As stated in the 
report for the Central Bank of Jordan in 2017, Jordan was characterized as a high emigration of workers that lead to an increase in remittances of Jordanian workers working abroad; and all that because of the challenges that the Jordanian economy faced it; such as increasing the unemployment rates that help to rely on the foreign aid, remittances, and on the domestic and foreign debt. Figure (1) showed that the remittances of migrant workers outside Jordan registered $\$ 54,366.10$ million by a report from the Central Bank of Jordan (1997 - 2017), and it is seen from figure (1) that the Jordanian migrant worker's remittances are a significant element for the contribution of the economy's prosperity, Hence, Jordan has recognized the economic importance of remittances of migrant workers. These remittances recorded their highest rates in 2015, which reached \$3,417.9 million (CBJ, 2017).

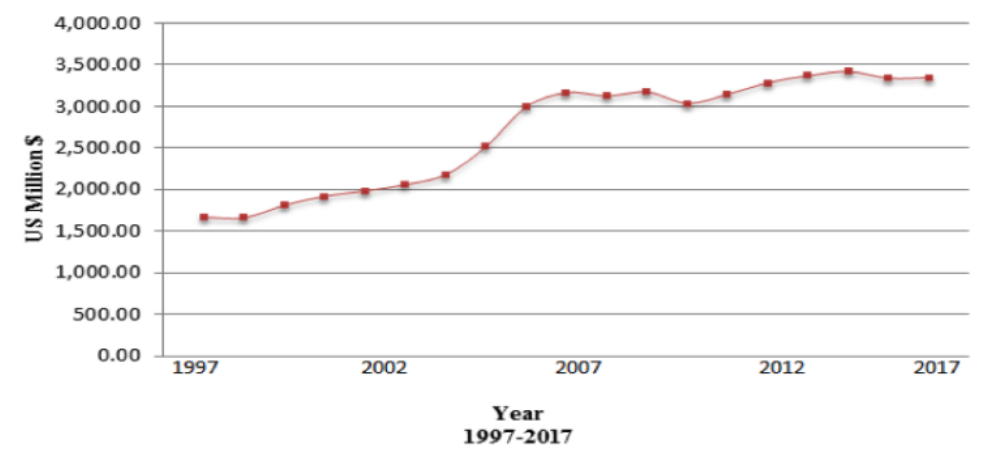

Figure 1: Migrant worker's Remittances in Jordan (1997-2017); Source: CBJ, 2017

Jordan needs external funding sources because it is necessary and important for various sectors which can make macroeconomic changes, and due to the political and economic conditions that affect the Jordanian GDP. In general, there are many researchers have studied the impact of external funding flow to the economic growth in various countries; where this study differed from other studies that dealt with foreign aid not as a single independent variable, as it took both grants and soft loans as separate independent variables that affect Jordan's GDP besides studying other variables such as; foreign direct investment, and the Jordanian migrant worker's remittances. In this study, it is attempted to find answer to a set of questions related to the impact of external funding flow (grants, soft loans, foreign direct investment (FDI), and Jordanian migrant worker's remittances) on Jordan's GDP (1997-2017), Also, This research also clarifies how the flow of external funding sources has developed in Jordan over the twenty years (1997 - 2017).

Jordan sought to have external funding sources flow because of the difficulties that faced it such as; the shortage of domestic savings through which the objectives of economic and social development can be achieved. The significance of this study determined whether if there was a statistically significant or no statistically significant impact of the external funding flow (grants, soft loans, foreign direct investment, and the Jordanian migrant worker's remittances) on Jordan's GDP (1997 - 2017).

External funding is one of the most important elements that contributes to the economic development in developing countries, thus the government of those countries highly depends on external funding flow; In addition, the domestic saving that already exists so as to improve the standards of living (Johnson \& Martin, 2004). This section includes empirical research examining the impact of external funding flow sources such as; grants, soft loans, foreign direct investment, the inflow of worker's remittances, and any other factors that affect the economic growth generally.

A study by Husein (2018) investigated the impact of external funding on the Jordanian economy for a long term from (1970 - 2014), and assessed whether if the economic policy in Jordan promoted the economic growth or not; and whether these methods of the external funding are conditional under certain circumstances in a political and economic level. The statistical analysis of the study variables is carried out and found that there is a positive effect of official development assistance (ODAY), workers' remittances (WTY), exports (XG), local savings (SY), and human capital (HCI) in the long term, which boosted Jordanian economic growth from $(1970$ - 2014). As for the economic policy in Jordan, it did not have a positive impact to promote economic growth contrary to what was proposed by the World Bank.

A further study was conducted by Raza et al. (2011) and investigated the impact of foreign capital inflows on economic growth in Pakistan (1985 - 2010), so the researchers dealt with various types of external funding in their study such as foreign direct investment, foreign aid in various forms, and worker's remittances that impact the GDP in Pakistan. The researchers conducted an analysis of the standard regression technique and the results showed that there is a positive effect of foreign direct investment and worker's remittances on the Pakistani economy, but there is a negative impact of foreign aid in its various forms on the Pakistani economy.

A study by Kabete (2008) examined the impact of foreign aid on the economic growth in Tanzania during the period from (1960 2004). The researcher obtained the data from the World Bank and the Ministry of Planning and Development in Tanzania, and in this study, the dependent variables are four as follow; the inflow of aid, net national saving, export growth, and debt service, in which these four variables showed the impact on the independent variable that represented with the (GDP) gross domestic product growth rate. The results of this study showed that there is a negative impact for foreign aid on economic growth in Tanzania more than positive impact, as for the independent variables that addressed in this study, the net national savings and export growth have a positive impact on the economy as expected for the researcher, so it helps the country to increase the ability for having investment 
projects and exporting products that contribute the economic growth. For the other two variables; the aid inflow and total debt service both of these variables have a negative impact because the government of the state of Tanzania did not use it for the purposes of social expenditures or in the investment sector, but used to support of the general state budget.

The researcher Ali (2013) dealt with the study of the impact of foreign aid on economic growth in Egypt (1970 - 2010), and in this study, the researcher used annual data from the World Bank. So for the GDP per capita as a dependent variable, it was used to measure economic growth, and for the independent variables that used in this study were; the net official development assistance (ODA) was used to measure the foreign aid and trade openness. The study found that there is a negative and non-significant impact of foreign aid on the Egyptian economy in the short term and long term. Also, the results found that there is a negative and nonsignificant impact of trade openness on economic growth in the long term, but it has a significant and positive impact on growth in the short term.

Alkaldi (2008) analyzed the impact of external aid on economic development in Jordan from 1990 to 2005 using various statistical methods. The researcher examined the impact of the two independent variables which are (ODA) and debt, and their effect on the dependent variable which was GDP. The results of the analysis showed that there is a positive impact of the inflow of foreign capital (ODA) on economic development, and for external loans (debt) that had a negative impact on the economic growth because it has been used it in different sectors (productive sectors, infrastructure ... etc.), but without repressive policies, the impact of foreign aid on Jordan's economic growth has a negative impact because there was mismanagement how to use the foreign capital. A study by Touama (2015) investigated the impact of foreign direct investment (FDI) on the economic development in Jordan from 1996-2008, and how much it contributed to the growth and stimulation of economic growth through using a modern technology method, advanced management and production methods, creating new jobs for local workers, and increasing GDP. The results of the study showed that there is a statistically significant impact of foreign direct investment on the Jordanian economy, so it is found that there is a positive relationship between investment and economic growth in Jordan for a long term and short term, also the study revealed the limited foreign investments in the Jordanian economy, despite the significant impact of foreign direct investment on the Jordanian economy.

The importance of studying the impact of foreign direct investment (FDI) on economic growth is becoming increasingly important. Among these researches, there is a study conducted by Fawwaz (2016) in which he discussed the importance of foreign direct investment to economic growth in Jordan from 2000 to 2013 and its contribution to stimulating the Jordanian economy. This research examined the logarithmic model which included the study of the impact of foreign direct investment, economic openness, financial development, commodity exports as independent variables and their impact on the real growth of GDP as a dependent variable. The results of the study showed that the contribution of foreign direct investment in the Jordanian economy was simple and the extent of its contribution in it was a little, despite the significant impact of foreign direct investments in Jordan, also the FDI does not support the industrial sector in Jordan. For the export component, it has a stronger and positive impact on economic growth, and for the economic openness and the financial development have a negative impact on economic growth in the long term, wherein on the contrary for the short term.

According to another research carried out by Acquah (2013) it showed the impact of foreign direct investment (FDI) on the local investment that affect the economic growth for 36 African countries in sub-Saharan Africa from 1980 to 2014. The analysis of the study was divided into two periods, the first period was from 1980 to 1994 and the second period was from 1995 to 2014 . The objective of this study is to investigate the impact of foreign direct investment (FDI) on local investment in sub-Saharan Africa to 36 countries in Africa. The results showed that there is a positive impact for foreign direct investment that effect on the local investment in 36 countries in the second period rather than the first period, also it helped these countries to improve their economy in the second period, due to the effectiveness of policies and initiatives adopted by the African Union, which contributed to increase the attraction of investment inside. A study by Shafqat et al. (2014) investigated the impact of migrant workers remittances in the economic growth in Pakistan by using time series data from (1991 - 2010). The dependent variable which used in the study is the natural log of GDP per capita (GROWTHi), and for the independent variables are; worker remittances that received to the country (WORREMi), ratio of money (FINDEVi), household consumption expenditure (CONSUMi), ratio of gross domestic savings (SAVINGi), and current account balance (CABALi) where this study analyzed the effect of the five independent variables and their impact on the dependent variable. The results showed that there is a positive relationship between the foreign remittances of expatriate workers and economic growth. The remaining variables also have an impact on economic growth in Pakistan, and for the financial development variable it has a positive impact on the Pakistani economy, and the household consumption rate has a positive impact on economic growth through increased household expenditure per household that contributed to increased consumption which affected the economic growth. As for the domestic savings for GDP and its relation to economic growth, the relationship is negative. As for the ratio of the current account balance to the gross domestic product, the relationship is either negative or positive by the circumstances.

A study by the researchers Kratou \& Gazdar (2014), investigated the impact of migrant worker's remittances on economic growth in the 12 Middle East countries (1984 - 2011). Through this study, the results showed that there is a positive impact for workers remittances on the economic growth for the long-term, but their impact in the short term is negative in the 12 Middle East countries, and the effect of workers remittances on economic growth is negative because there are a set of conditional policies; where the countries could benefit from the workers remittances and their impact on economic growth when they have a robust financial system. 
A study conducted by researchers Kundu et al. (2012) that investigated the effect of migrant workers' remittances on the macroeconomic in Bangladesh (1976 - 2010). The variables studied by the researchers are four independent variables; Migrant worker's remittances, foreign direct investment, official development assistance, and inflation rates, which have an impact on GDP growth in Bangladesh, and these four independent variables, are a part of macroeconomics and economic growth. The statistical analysis showed that there is a positive relationship between expatriate workers remittances, foreign direct investment, and official development assistance with the economic growth in Bangladesh. In contrast, the inflation rate of Bangladesh has a negative relationship with migrant workers' remittances inflow which negatively affects the economic growth in Bangladesh.

\section{Research and Methodology}

This study dealt with the impact of external funding flow on Jordan's GDP (1997 - 2017) based on analytical method to have an accurate and detailed knowledge about the importance of external funding flow and its impact on Jordan's GDP, through analysis of data that issued by the Ministry of Planning and International Cooperation, the Central Bank of Jordan, the Ministry of Finance, the Ministry of labor, and Jordan Investment Commission.

Time series analysis used to test the hypotheses of this research through the E-Views statistic program which helped to access to powerful statistical forecasting, and modeling tools, to investigate the importance and the role of external funding flow (grants, soft loans, foreign direct investment, and the Jordanian migrant worker's remittances) and its impact on Jordan's GDP (1997 - 2017). And it verified the impact of these four independent variables on the dependent variable (GDP).

According to the model that used by Kundu, et al. (2012), the researchers examined four main sources of external funding flow in their study; The official development assistance (ODA) includes grants and soft loans together, foreign direct investment (FDI), worker's remittances (WREM), and the inflation rate (INFRAT), which used the current USD price with all variables, in which all of these variables have a positive or negative relationship with GDP growth in Bangladesh.

This study has adopted the model that referred to Kundu, et al. (2012); where the official development assistance was divided into two separate variables the first variable is grants (GR) and the second one is soft loans (LN), each variable was studied independently, in addition, this study presented the foreign direct investment (FDI) and Jordanian migrants worker's remittances (JMWR) and their impact on Jordan's GDP (1997 -2017). The main reason for using this model that belongs to Kundu, et al. (2012) is to investigate the economic situation and how GDP in Jordan affected by the external funding flow for twenty years, which helped to describe the phenomenon that was studied. This research does not answer the questions about how this happened, or how it happened, rather than that, it's about the structure of external funding flow and its impact on Jordan's GDP $(1997$ - 2017).

The research aimed to investigate the relationship between the dependent variable (GDP) and independent variables, and it's examined four main sources of external funding flow; grants (GR), soft loans (LN), foreign direct investment (FDI), and Jordanian migrant worker's remittances (JMWR) and their impact on Jordan's GDP, where the researchers clarified the equation as follow;

$$
\mathrm{Y}=\alpha+G R+L N+F D I+J M W R
$$

Where $(\boldsymbol{Y})$ represents the total of GDP in Jordan, and for $(\boldsymbol{\alpha})$ represent any other factors that impact on the Jordan's GDP, for $(\boldsymbol{G R})$ grants, $(\boldsymbol{L N})$ for soft loans, $(\boldsymbol{F} \boldsymbol{D} \boldsymbol{I})$ for foreign direct investment, and $(\boldsymbol{J M W} \boldsymbol{R})$ for Jordanian migrant worker's remittances, so for more details, the model equation is explained as follows:

$$
Y=\alpha_{i}+\alpha_{1}(G R)_{t}+\alpha_{2}(L N)_{t}+\alpha_{3}(F D I)_{t}+\alpha_{4}(J M W R)_{t}+\varepsilon_{t}
$$

Table 2: Data Descriptive

\begin{tabular}{ll}
\hline Y: GDP in Jordan & $\boldsymbol{\alpha}_{\boldsymbol{i}}$ : Express any other factors that impact on the Jordanian economy \\
\hline (GR) : Grants & $\alpha_{1}$ : Express the impact of (GR) on (Y) \\
\hline (LN): Soft loans & $\alpha_{2}$ : Express the impact of (LN) on (Y) \\
\hline (FDI): Foreign direct investment & $\alpha_{3}$ : Express the impact of (FDI) on (Y) \\
\hline (JMWR): Jordanian migrant workers remittances & $\alpha_{4}$ : Express the impact of (JMWR) on (Y) \\
\hline t: Period of time & $\varepsilon=$ Error Term \\
\hline
\end{tabular}

Table (2) is brief for the data descriptive in this study which helped to describe and understand the features of the dependent and independent variables in this study.

\section{Study sample}

This study analyzed through secondary data, and the researchers studied the impact of external funding flow on Jordan's GDP during the period (1997-2017/ 20 years) through using these sources of data:

- Ministry of Planning and International Cooperation (MOPIC) - The government of Jordan (data for grants and soft loans from 1997 - 2002). 


\author{
Ministry of Finance - The government of Jordan (data for all the independent variables from 2003 - 2017). \\ Ministry of Labor - The government of Jordan (data for the Jordanian migrant's workers remittances from 1997 - 2002). \\ The Central Bank of Jordan (CBJ) (data for all the independent variables from 2003 - 2017). \\ Jordan Investment Commission (JIC) (data for foreign direct investment from 1997 - 2002). \\ World Bank/ World Development Reports / (GDP data from 1997 -2017).

\section{Independent variables}

\title{
Grants and soft loans
}

Grants and soft loans are sorts of foreign aid and considered as the main source of external funding that contributes to improving the economy of developing countries. The term foreign aid means a formal flow of funding from donor countries to developing countries for helping them to build up their economy. Where the Organization for Economic Cooperation and Development (OECD, 2012) defined foreign aid as a financial flow as grants, soft loans or technical assistance which designed to contribute in the economic and social development in developing countries as their main objectives are to reduce the poverty, raising the standard of living of persons, contributing to transfer the skills and technologies, increasing product diversity, and generates employment. The term "grants" as a type of foreign aid, the Ministry of Planning and International Corporations (MOPIC) in 2019 defined it as a process which transfers the funds from a state or government to the government of developing country to fund in a particular project or program, and this type of grant is not required to be paid, and it must be spent by the instructions and guidelines of the grantor.

The second variable is soft loans that are concessional financing to the government as loans but with soft financing terms and conditions. In Jordan for example; there is a coordination between the Ministry of Planning and International Cooperation and the donor of the soft loans which was agreed that the interest rate in Jordan for the soft loans should be between $(0.75 \%-2.8 \%)$ and the repayment period shall be (35) years with a grace period for the repayment between (3-10) years, and these loans are given with a low level of interest rates to schedule a set of previous debts and provide real opportunities for public and private investment in Jordan (MOPIC, 2019).

\section{Foreign direct investment}

The International Monetary Fund in (2003), defined foreign direct investment (FDI) as one in which the long-term relationship between a direct investment institution and a direct investor is realized, and the objective is to obtain an ongoing interest in an economy (which is represented with the direct investor) by obtaining an interest through a foreign institution which is a resident in another economy (which is represented with the foreign investment institution). Foreign Direct Investment (FDI) is not only based on the relationship between the direct investor, and the direct investment institution as other capital factors influence this relationship. At the same time, foreign direct investment does not mean that the foreign-invested institution must control (100\%) the investment project, where the ownership for the foreign investor should be (10\%) and (90\%) of this property belong to the local investor (IMF, 2003).

\section{Migrant's workers remittances}

Migrant worker's remittances play an important role in developing countries because it currently represents a large source of income in many of these countries, and there is a data released by the International Organization for Migration (IOM) in 2009, showed that the remittances from abroad are considered to be the financial sources in the developing countries. The United Nations in 2005, defined migrant remittances as personal cash remittances made by the workers and sent to their relatives in their origin, in which they can be sent their remittances in different ways, through banks, money transfer operators or other financial institutions.

\section{The dependent variable}

\section{Gross domestic product (GDP)}

Gross domestic product is an economic indicators that track the health of a country's economy and primarily used to measure the economic performance and the total market value of final goods and services that are produced in a given region with a specific period (Ulfah, 2015).

There are four main components of GDP; consumption, investment, government spending, and net exports. The formula for calculating the components of GDP is; consumption (C) + investment (I) + government expenditure (GE) + net exports (EX) (which is exports - imports). There are two types of gross domestic product; the first one is nominal GDP, in which current market prices are taken without taking the coefficient of inflation or deflation. The second type is the real GDP which is calculated by using the coefficient deflation. Economists generally prefer to use real GDP as a means of comparing a country's economic growth rate (Amadeo, 2019).

\section{Research Hypotheses}

H01: There is no statistically significant impact of external funding flow on Jordan's GDP (1997-2017).

Sub Hypotheses:

H02: There is no statistically significant impact of grants (GR) on Jordan's GDP (1997 -2017).

H03: There is no statistically significant impact of soft loans (LN) on Jordan's GDP (1997-2017). 
H04: There is no statistically significant impact of foreign direct investment (FDI) on Jordan's GDP (1997-2017).

H05: There is no statistically significant impact of Jordanian migrant worker's remittances (JMWR) on Jordan's GDP (1997-2017).

Regression results

The main purpose of this study is to answer the research question here is whether there is an impact of the external funding flow on Jordan's GDP (1997 - 2017) which involved the analytical techniques, which were used to analyze the time-series data from (1997 - 2017). Some statistical methods were used including; multicollinearity, unit root test, correlation test, and regression coefficient; through used the E-views program for general statistical analysis and econometric analyses.

\section{Multicollinearity:}

For the purpose of using multiple regression, table (3) showed that the tolerance test values and Variance Inflation Factor (VIF) that all tolerance values were more than 0.1 and Variance Inflation Factor -VIF values of independent variables were less than 10, therefore, it can be assumed that there is no problem related to multicollinearity between independent variables (Paul, 2017).

Table 3: Multicollinearity

\begin{tabular}{lll}
\hline Variable & Tolerance & VIF \\
\hline Grants & .286 & $\mathbf{3 . 4 9 5}$ \\
\hline Soft Loans & .749 & $\mathbf{1 . 3 3 6}$ \\
\hline Foreign Direct Investments & .313 & $\mathbf{3 . 1 9 4}$ \\
\hline Jordanian Migrants Worker's Remittances & .166 & $\mathbf{6 . 0 4 1}$
\end{tabular}

\section{Unit Root and Stationary Test:}

This test was used to find out the possible equilibrium relationship between variables, which can be justified through using regression analysis; the first step is to test the time series sample for stationary. ADF test was used and the obtained results for the all-time series used in this research are as follow (Glen, 2016).

Table 4: ADF Test Results

\begin{tabular}{|c|c|c|c|}
\hline Variable & $\mathbf{t}$-statistics & $5 \%$ critical value & $\mathbf{p}>|\mathbf{t}|$ \\
\hline Grants (GR) & -4.764 & -3.691 & 0.007 \\
\hline Soft Loans (LN) & -8.073 & -3.691 & 0.000 \\
\hline Foreign Direct Investments (FDI) & -3.901 & -3.674 & 0.033 \\
\hline $\begin{array}{lcc}\text { Jordanian } & \text { Migrant } & \text { Workers } \\
\text { Remittance (JMWR) } & \\
\end{array}$ & -33.747 & -3.674 & 0.001 \\
\hline GDP & -8.271 & -3.691 & 0.001 \\
\hline
\end{tabular}

Table (4) indicated that $\mathrm{P}>|\mathrm{t}|$ values are significant at a 5\% level, therefore the hypothesis is rejected and the alternative one is accepted. This means that the series is stationary and no unit roots exist. Table (4) showed that the absolute value of (t-statistics) is larger than (t critical); this means that the hypothesis is rejected. So based on that there are no unit roots in the sample time series, and then the stationary and integrated are at the level I (0).

\section{Correlation test}

Correlation analysis used for the purpose of identifying the strength of relationships between a pair of variables. The correlation coefficient $(\mathrm{R})$ values vary between -1 and +1 . The perfect collinearity is \pm 1 and 0 . Values of $(\mathrm{R})$ between 0 and 1 reflect a partial correlation, which can be significant or non-significant. Only correlations that are significant at $p<0.05$ or 0.01 should be considered. Table (5) indicated that there is a relationship between independent variables keep the Jordanian migrant workers' remittances and dependent variable since sig values are less than 0.05 for grants, soft loans, and foreign direct investment (Chen \& Popovich, 2002).

Table 5: Correlation Test

\begin{tabular}{llllll}
\hline Probability & GDP & FDI & GR & LN & JMWR \\
\hline GDP & 1.000000 & & & & \\
\hline FDI & $0.499151^{* *}$ & 1.000000 & & & \\
\hline GR & $0.828417^{* *}$ & 0.293742 & 1.000000 & 1.000000 & \\
\hline LN & $0.722127^{* *}$ & 0.165501 & $0.700037^{* *}$ & 0.076703 & 1.000000 \\
\hline JMWR & -0.029939 & -0.121322 & -0.055423 & \\
\hline
\end{tabular}

Note: significant level $* * 1 \%$ and $* * 5 \%$

The person correlation test showed that there is a high correlation between some of the relations (i.e. the observations higher than (0.8). However, as another step for check multicollinearity this study using (VIF) and its tolerance (1/VIF), the results showed there is no multicollinearity problem between study variables. The results are less than 10 for the (VIF) and more than (0.1) for tolerance (Chen \& Popovich, 2002). 


\section{Regression Results}

From the table (6), the Adjusted R square measured the proportion of the variance in the dependent variable (GDP) that explained by variations in the independent variables (GR, LN, FDI, JWMR). I.e., adjusted R square showed that (76\%) of the variance explained. $\mathrm{R}$ square measures the proportion of the variation in the dependent variable (GDP) that explained by variations in the independent variables (GR, LN, FDI, JWMR). In the table (6), the R-Square showed that (80\%) of the dependent variable (GDP) explained by the independent variables (GR, LN, FDI, JWMR).

Table 6: Regression coefficient

\begin{tabular}{lllll}
\hline Variable & Coefficient & Std. Error & t-Statistic & Prob. \\
\hline Constant & 1758.533 & 3273.415 & 0.537217 & 0.5985 \\
\hline Grants (GR) & 9.902 & 2.995435 & 3.306 & 0.005 \\
\hline Soft Loans (LN) & 10.364 & 5.439604 & 1.905 & 0.075 \\
\hline Foreign Direct Investment (FDI) & 3.636 & 1.438091 & 2.528 & 0.022 \\
\hline $\begin{array}{l}\text { Jordanian Migrants workers Remittances } \\
\text { (JMWR) }\end{array}$ & 0.051 & 0.465994 & 0.109 & 0.914 \\
\hline R-squared & & & \\
\hline Adjusted R-squared & 0.80 & Mean dependent var & 20684.08 \\
\hline S.E. of regression & 0.76 & S.D. dependent var & 11853.57 \\
\hline Sum squared resid & 5861.692 & Akaike info criterion & 20.39452 \\
\hline Log likelihood & $5.50 \mathrm{E}+08$ & Schwarz criterion & 20.64322 \\
\hline F-statistic & -209.1425 & Hannan-Quinn criter. & 20.44849 \\
\hline Prob(F-statistic) & 16.44668 & Durbin-Watson stat & 1.784429 \\
\hline
\end{tabular}

\section{Discussion}

The Analysis has indicated that the total of the independent variables (grants, soft loans, foreign direct investment, and Jordanian migrant workers' remittances) had an impact on Jordan's GDP (1997 - 1997). However, this impact was not absolute. Since the data indicated that in some years, despite the increase in the total number of factors mentioned that the gross domestic product (GDP) is declined, indicating that there are other factors affecting the GDP.

The researchers linked the results of the previous studies with the results that featured in their study as below:

\section{Grants (GR)}

According to the reports from the Ministry of Planning and International Corporation (MOPIC) in 2019, indicated that grants have an impact on Jordan's GDP, but this impact isn't absolute. The data indicated that grants declined in some years during the twenty years (1997- 2017), and GDP continued to increase, indicating other factors affecting GDP.

The result is confirmed by the hypothesis which states that there is a statistically significant impact at $(\alpha=0.05)$ level of grants on the GDP in Jordan from (1997 -2017), such as the result that agreed with Alkaldi (2008), who have found that foreign aid had a positive impact on the economic growth in Jordan. On the other hand, the results of this research do not agree with a study by Kabete (2008), who have found that the inflow of aid had a negative impact on the economic growth in Tanzania, and a study for Ali (2013), found that there is a negative impact of foreign aid on the Egyptian economy which does not agree with the results of this research.

\section{Soft loans (LN)}

As for the soft loans based on the data from the Ministry of Planning and International Corporation (MOPIC) in 2019, indicated that there is an impact on Jordan's GDP, but this impact is not absolute. The data indicated that the soft loans declined in some years during the twenty years $(1997$ - 2017) and GDP continued to increase.

The results do not confirm with the hypothesis which states that there is no statistically significant impact of soft loans at $(\alpha=0.05)$ level on the GDP in Jordan from (1997 -2017) such as the result that agreed with Alkaldi (2008), who have found that the external loans had a negative impact on the economic growth in Jordan.

\section{Foreign direct investment (FDI)}

Foreign direct investment (FDI) has an impact on Jordan's GDP, but this impact is not absolute. The report from Jordan Investment Commission (JIC) in 2017 showed that despite the decline in foreign direct investment during the twenty years (1997 - 2017), GDP has continued to increase, indicating other factors affecting the gross domestic product. The results are confirmed that there is a statistically significant impact at $(\alpha=0.05)$ level of foreign direct investment on the GDP in Jordan.

The result is consistent with the study for Raza et al. (2011), who have found that there is a positive effect of the (FDI) on the Pakistani economy. Also, it has a consensus with Touama (2012), who found that there is a statistically significant impact of (FDI) on the 
Jordanian economy, so it was found that there is a positive relationship between (FDI) and economic growth in Jordan in a long term and short term. Also, a study for the researcher Fawwaz (2016), who found that the contribution of (FDI) in the Jordanian economy was simple and the extent of its contribution in it was a little.

This research agreed with Acquah (2013), who have found that these are an impact of foreign direct investment (FDI) on the local investment that effects on the economic growth, and with Kundu et al. (2012), who found that there is a positive relationship between foreign direct investments with the economic growth in Bangladesh.

\section{Jordanian migrant worker's remittances (JMWR)}

According to the report from the Ministry of Labor in 2017, the results show that the period from (1997-2006) there was an increase in Jordan's GDP, and this increase was accompanied by a rise in the Jordanian migrant worker's remittances except in (1998). There is a continuous increase in GDP, accompanied by an increase in remittances of workers except for the year (2009), which showed a decline in workers remittances was not accompanied by a decline in the gross domestic product, also it appeared from the data that the Jordanian migrant workers remittances have an impact on Jordan's GDP, but this effect is not absolute. The data indicate that workers' remittances declined in some years over the twenty years (1997-2017), and GDP continued to increase, indicating other factors affecting output GDP.

The results of the study confirmed that there is no statistically significant impact at ( $\alpha=0.05)$ level of migrant worker's remittances on the GDP in Jordan, which is not consistent with the study for Marwan et al. (2013).

The results also do not agree with Shafqat et al. (2014) found that there is a positive relationship between the worker's remittances of expatriate workers and economic growth in Pakistan, and does not agree with a study by Kratou \& Gazdar (2014), found that there is a positive impact for worker's remittances on the economic growth in MENA countries for the long-term, also with Kundu et al. (2012), found that there is a positive relationship between expatriate workers' remittances with the economic growth in Bangladesh that does not agree with the result of this research.

\section{Conclusion}

External funding sources considered an important source of funding in developing countries and continued to play a multifaceted role in financing their development needs, so this study conducted to investigate the impact of external funding flow (grants, soft loans, foreign direct investment, and Jordanian migrant worker's remittances) in Jordan's GDP (1997 - 2017).

This study differed from other studies in which it was dealt with foreign aid, not as a single independent variable, so the researchers took grants (GR) and soft loans (LN) as separate independent variables that effect on Jordan's GDP (1997 -2017) in addition, studying other variables such as; foreign direct investment (FDI), and the Jordanian migrant worker's remittances (JMWR) on Jordan's GDP for the same period.

Through this study, the researchers attempted to choose the hypothesis which was mainly about; there is no statistically significant impact of external funding flow sources (GR, LN, FDI, JMWR) on Jordan's GDP (1997 - 2017). Where a standard model that derived from (Kundu, et al., 2012) tested if there is no statistically significant impact between the four independent variables of external funding sources (Grants, Soft loans, foreign direct investment, and Jordanian migrant worker's remittances) with the dependent variable which was Jordan's GDP from $(1997$ - 2017).

The study focused on the importance of external funding flow on Jordan's GDP (1997- 2017) through using the E -Views statistic program and multiple regression approach. The researchers analyzed the impact of external funding flow on Jordan's GDP for the period (1997-2017) and found that grants (GR) and foreign direct investment (FDI) have a statistically significant impact on Jordan's GDP; in contrast, soft loans (LN) and the Jordanian migrant's worker's remittances (JMWR) have no statistically significant impact on Jordan's GDP for the same period.

\section{References}

Acquah, J. (2013), Impact of foreign direct investment on domestic investment: evidence from Sub-Saharan Africa, published thesis, Kwame Nkrumah University of Science and Technology.

Ali, H. (2013), Foreign aid and economic growth in Egypt: a cointegration Analysis, International Journal of Economics and Financial Issues, 3 (3): 743-751.

Alkaldi, M. (2008). Impact of foreign aid on economic development in Jordan (1990-2005), Journal of social sciences, 4 (1): 16-20.

Amadeo, K. (2019), Components of GDP explained, Available at: https://www.thebalance.com/components-of-gdp-explanationformula-and-chart-3306015, (Accessed: 1 November 2019).

Chen, Y \& Popovich, M. (2002). Correlation: Parametric and nonparametric measures. Thousand Oaks, CA: Sage Publications.

Fawwaz, T. (2016). foreign direct investment and economic growth in Jordan (2000- 2013), Journal of social sciences, Jordan university, 1 (43): 617-627.

Glen, S. (2016), Unit Root: Simple Definition, Unit Root Tests, Available at: https://www.statisticshowto.datasciencecentral.com/unit-root/, (Accessed: 20 December 2019). 
Husein, J. (2018), Foreign aid, workers' remittances and economic growth in Jordan, published thesis, Angelo State University. Idris, I. (2016), Economic situation in Jordan, University of Birmingham: (K4D) knowledge, evidence and learning for development. Johnson,A \& Martin,M. (2004), Key analytical issues for government external financing, second edition, London: Debt relief international Ltd.

Jordan Investment Commission. (2017), General information about Jordan investment commission, Available at:https://jordan.gov.jo/wps/portal/Home/GovernmentEntities/Agencies/Agency/Jordan

$\% 20$ Investment $\% 20$ Commission?nameEntity=Jordan\%20Investment $\% 20$ Commission\&entityType=otherEntity\&lang=en\& isFromLangChange=yes, (Accessed: 14 June 2019)

Kabete, C. (2008), Foreign Aid and Economic Growth: The Case of Tanzania, published thesis, Institute of social studies.

Kratou,H \& Gazdar,K (2014). Addressing the effect of workers' remittance on economic growth: evidence from MENA countries, International Journal of Social Economics, 43 (1): $51-70$

Kundu, et al., (2012). Workers' Remittances Impact on the Economic Growth: Evidence from Capital Inflows in Bangladesh, the Jahangir agar Journal of Business Studies, 2 (1): 153 - 167.

Maingi, K. (2014), the effect of foreign direct investment on economic growth in Kenya, published thesis, University of Nairobi.

Marwan et al. (2013). Export, Aid Remittance and Growth: Evidence from Sudan, Procedia Economic and finance, 7 (3): 3-10.

Ministry of finance. (2018), Draft General Budget for 2018, Available at: http://www.gbd.gov.jo/GBD/en/Budget/Index/generalbudget-law, (Accessed: 10 December 2018).

Ministry of Labor (2017), Annual report of 2017, Jordan: Ministry of labor.

Ministry of planning and International Corporation. (2019), Foreign aid reports, Available at: http://www.mop.gov.jo/DetailsPage/PartAr.aspx?CourseID=10, (Accessed: 4 March 2019).

Mladen, M. (2015). Economic growth and development, (JPMNT) Journal of Process Management - New Technologies, International, 3 (1), $55-61$

Paul, R. (2017), Multicollinearity: Causes, effects and remedies, Library Avenue, New Delhi.

Raza et al. (2011), Capital inflows and Economic growth in Pakistan, published thesis, Iqra University.

Shafqat, M, et al. (2014), Impact of Worker Remittances on Economic Growth of Pakistan: Analysis of Pakistan's Economy, Journal of business research Turk, 6 (2): 6-14.

The Central Bank of Jordan (2017), Annual Report 2017, Available at: http://www.cbj.gov.jo/EchoBusV3.0/SystemAssets/5c395f60ea7f-4da5-8897-d046f33b75f4.pdf, (Accessed: 15 March 2019).

The International Monetary Fund - IMF. (2003), Foreign direct investment trends and statistics: A summary, Available at: https://www.imf.org/External/np/sta/fdi/eng/2003/102803s1.pdf, (Accessed: 15 March 2019).

The International Organization for Migration -IOM. (2009), IOM and Remittances 2009, Geneva, Switzerland: International Organization for Migration.

The Organization for Economic Cooperation and Development - OECD. 2012, Official development assistance - definition and coverage, Available at: https://www.oecd.org/dac/stats/officialdevelopmentassistancedefinitionandcoverage.htm (Accessed: 30 June 2019).

The World Bank. (2018), Overview - The world bank in Jordan, Available at: https://www.worldbank.org/en/country/jordan/overview, (Accessed: 2 November 2019).

Touama, H. (2015), The impact of foreign direct investment on the economic development in Jordan - An analytical econometric study period (1996 - 2008), Zarqa Journal for Research and Studies in Humanities, 15 (1): 258-267.

Ulfah, R. (2015), Understanding the Prevalent Use of GDP as an Indicator of Development Progress, Available at: http://edepot.wur.nl/337084, (Accessed: 12 December 2018).

United Nations. (2005), Definition of Personal Remittances in the Balance of Payments Context in Jordan, the IMF Committee on Balance of Payments Statistics, Washington, D.C.

Publisher's Note: SSBFNET stays neutral with regard to jurisdictional claims in published maps and institutional affiliations.

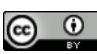

(C) 2021 by the authors. Licensee SSBFNET, Istanbul, Turkey. This article is an open access article distributed under the terms and conditions of the Creative Commons Attribution (CC BY) license (http://creativecommons.org/licenses/by/4.0/).

International Journal of Research in Business and Social Science (2147-4478) by SSBFNET is licensed under a Creative Commons Attribution 4.0 International License. 